\title{
Anti-German Sentiment in Iowa During World War I
}

Leola Allen

During the First World War immense pressure was brought to bear on Americans to support the war effort. The federal goverment created a number of agencies that assumed considerable control over traditionally private enterprises. The passage of a national sedition act increased governmental power over thought and speech. Concern for the loyalty and patriotism of all Americans approached paranoia in many sectors of the nation. lowa was particularly affected because many lowans were of German birth or ancestry. The following article deals with some of the pressures and problems during this period and the general response to these difficulties.

WILLIAM L. HARDING, A REPUBLICAN born in Osceola on October 3, 1877, was Iowa's war-time governor. He practiced law in Sioux City and became involved in politics by campaigning for a Republican reform candidate for mayor there. The man lost but Harding's oratory was not forgotten. In 1907, he was elected representative from Woodbury County to the 32nd General Assembly where he earned a reputation as a moderate willing to work hard in drafting legislation. He remained a member of the legislature until elected lieutenant governor in 1911, serving two terms in that office. He was elected governor in 1916. Harding has been described as a professional politician who "adapted his politics to suit needs of the hour."1

'John E. Visser. "William Lloyd Harding and the Republican Party in 
Harding, while not outwardly questioning the loyalty of German-Americans, felt the various nationalities living in Iowa could and should become more thoroughly Americanized. The governor expressed the belief that "misunderstandings" resulted from the use of foreign languages.

On May 23, 1918, Governor Harding issued a proclamation banning the use of languages other than English. ${ }^{2}$ Harding stated that he did not believe this proclamation violated the free exercise of religion. An immediate reaction in the form of a vigorous protest was heard from the Bohemians in Cedar Rapids. Governor Harding received telegrams from them protesting the scope of the proclamation. ${ }^{3}$ Dutch, Danes, Swedes and others soon added their protests.

Yet one German-American, and presumably the organization he represented, applauded the governor's stand. Reverend John C. Orth, president of the German-American patriotic Association of Iowa affirmed, "It is impossible to have complete loyalty in this state as long as there is a great faction fighting to preserve the German language. ... The German language is not needed for anybody's convenience. . . ."4

Editorially the Des Moines Register described the order as "ill-considered" and called for its withdrawal immediately. Lawyers they had consulted felt it was an illegal order that unnecessarily upset many good people. ${ }^{5}$ Earlier, the Register seemed to favor ending the use of German but objected to including all other foreign languages.

Questions about the legality of the order further confused the issue as ministers at Cedar Falls and Fredsville ignored the language proclamation and continued to conduct services in Danish. They received advice to do so from the Black Hawk and Grundy County attorneys. ${ }^{6}$ Debate over whether or not the order was legal

Iowa," (unpublished Ph.D. thesis, University of lowa, 1957), pp. 10, 14, 15, 16, 37. 94, 174.

${ }^{2}$ W. L. Harding, "lowa War Proclamations," Iowa and the War, No. 13, ed. B. F. Shambaugh (lowa City: State Historical Society of lowa, July, 1918), pp. 45-6.

${ }^{3}$ Des Moines Register. May 26, 1918, p. M-10.

${ }^{4}$ Des Moines Capital, May 30, 1918; August Richter manuscript collection (lowa City: State Historical Society of Iowa), hereafter city ARC.

'Des Moines Register, June 1, 1918, p. 4.

${ }^{\circ}$ Des Moines Register. June 10, 1918, p. 1. 
and had to be obeyed arose in other areas of the state, too. In Tama County, the Traer Mutual Telephone Association consulted with their Advisory Board about the problem. The Board advised them that the governor's proclamation should be obeyed and was legal.?

The Reverend Henry Prekel, pastor of Immanuel Lutheran Church, Waterloo, announced plans to continue preaching in German fifty percent of the time. Reverend Baushoff, pastor of a German Evangelical Church at Denver in Bremer County continued to preach in German, also. Then state agents visited him and he signed a statement indicating he would comply with the proclamation. The main service would be conducted in English and the gospel repeated in German at an "after-meeting." ${ }^{8}$ Earlier reports had stated that the Reverend Baushoff said he would take up arms to defend his right to preach in German. The German community at Schleswig objected to the posting of the governor's language order. At Alta, Iowa, a Reverend Mennoich, the Lutheran pastor, was unable to preach in English and he refused a leave of absence in order to study the language. He subsequently was called before a board of military affairs, and promised to be "good."

Governor Harding traveled to several foreign language areas in the state to explain why he felt the proclamation was necessary. He said he had knowledge that pro-German propaganda and plots against the federal government were spread through Iowa by the use of all foreign languages, not just German. Harding contended that forbidding the use of foreign languages would curtail the activities of those few among the foreign language groups who were disloyal.

Cyrenus Cole, a Cedar Rapids newspaper editor who later represented Iowa in Congress expressed his chagrin in the following way:

... to tell him [Governor Harding] that if my mother were still living 1 would call her up on the telephone and in his hearing talk with her in a foreign language, and if he had me arrested for doing that, I would announce myself as a candidate for his office and defeat him. ${ }^{10}$

'Traer Star-Clipper, June 28, 1918, p. 1.

${ }^{8}$ Des Moines Register, June 22, 1918, p. 10; July 13, 1918, p.7.

Des Moines Captial. July 2, 1918; ARC; Des Moines Register. July 17. 1918.

${ }^{10}$ Cyrenus Cole. I Remember. I Remember, A Book of Recollections (lowa 
In Cole's view, the proclamation was one of the "foolish" things done in the name of patriotism. Connecting the sound of foreign speech with a decrease in patriotism seemed irrational. Cole claimed that American soldiers "comforted each other in the trenches and in dying in foreign languages and in the German language most of all" "1

Adding irony to the situation, President Woodrow Wilson requested citizens of foreign birth to plan Fourth of July celebrations in 1918-and one item of the program recommended patriotic speechs in foreign tongues. ${ }^{12}$ While the president apparently recognized that it was easier to reach a person in the language he understood best, Governor Harding's proclamation precluded this possibility in Iowa.

During the months after the governor's proclamation was issued, charges of pro-German sentiments continued. Incidents involving the splashing of yellow paint, appearances of "offenders" before extra-legal courts, and threats to those who did not vocally and financially support the war effort were disturbing to many. Often even a few words spoken in German on a street corner, over a telephone or in church led to fines, threats and grief for the German-Americans. In Scott County, four women were fined $\$ 225$ for speaking German on the telephones. The county council for defense donated the fines to the Red Cross. ${ }^{13}$

$$
\text { \# \# }
$$

The sale of Liberty Bonds, during five campaigns, was designed to raise money to support the war effort. Each federal reserve district received a quota and residents of the district were expected to subscribe that amount as a minimum. Individual quotas were based on various factors including property, income, and total net worth. These quotas were established by local quota committees. ${ }^{14}$

City: State Historial Society of lowa, 1936), p. 353.

"Cole, History of the People of low'a, pp. 450-1.

${ }^{12}$ Demokrat, Davenport, lowa, July 3, 1918, in ARC.

${ }^{13}$ Demokrat. June 15, 1918, quoted by Carl Wittke. German-A mericans and the World War (Columbus: The Ohio State Archaelogical and Historical Society, 1936), p. 187.

${ }^{14}$ Nathaniel R. Whitney, Sale of War Bonds in lowa (lowa City: State Historical Society of Iowa, 1923), pp. 14-28. 
The First Liberty Loan Campaign in May and June of 1917, and the Second in October, 1917, received little publicity and the public demonstrated little interest. Many predominantly rural counties, and some with large numbers of German-American residents, failed to reach their assigned quotas. The Third Campaign in the spring of 1918, the Fourth in the fall of the same year, and the Fifth in 1919 succeeded in reaching their quotas, and not solely because Iowans were better informed or more aware of the war issues. "Certain methods of pressures and coercion were devised which could not help but bring results." 15

The method used in Marshall County was typical and with variations was employed in other counties as well.

\footnotetext{
All war funds were alloted to its citizens according to their ability to pay. Liberty loans were alloted among the precincts upon the basis of assessed values of property; war stamps upon the basis of population; Red Cross and all welfare funds one-half upon the basis of property values and one-half upon the basis of population. Every citizen's assessable property was listed from the tax books, his income estimated by competent committees and each precinct quota in every drive was then alloted to its citizens as fairly in proportion to their ability to pay as committees of neighbors could distribute the war burden. ${ }^{16}$
}

Jasper and Chickasaw Counties used a property assessment method of setting quotas for the bond campaign. The patriotic census which Tama County took in November, 1919, included a valuation of property. This catalog also included a record of the citizens' Liberty Bond purchases and contributions to the various fund drives. Certainly such a list made it easier to apply pressure to those who had not purchased bonds when the Third Campaign began in April, 1918. The object of the survey was to distinquish between loyal Americans and those who were not. A person who failed to give enough was suspected of not being patriotic.

In some communities, Liberty Loan committees gave each citizen a card telling him how many bonds to purchase. Frequently warnings of the consequences which would follow a refusal acompanied such instructions. Assessments amounting to approximately two percent of the value of an individual's property were levied in some rural areas. In other areas, a person's share was determined by income, bank accounts, investments, and oc-

${ }^{15}$ Carl Wittke. German-Americans and the World War. p. 157.

10 Marshall County and the World War (Marshalltown: Joseph A. Whitacre and W. J. Moore, Marshall Printing Co.. 1919), p. 22. 
casionally even his borrowing capacity.

Citizens who failed to cooperate with these quasi-official orders were often compelled to appear before "slacker courts." Cedar Rapids had a "Loyalty Court," Sioux City an "Incognito Military Court," while Johnson County organized a "Loyalty League." Four hundred people answered summonses to appear before the court at Council Bluffs. This organization dealt with alleged disloyal remarks and failure of some citizens to contribute the correct amount to the war campaigns. "Not one dared to ignore the summons of this entirely extra-legal body." In Black Hawk County, the sheriff brought in those who failed to come before the "court" of their own free will and no one questioned his right to do so even though it was an extra-legal body. ${ }^{17}$

These "slacker courts" made their appearance at different times during and after the war. Jasper County had one in April and May of 1919 which is typical, except since it occurred after the war, returned servicemen participated. The Jasper County Council for Defense called on the returned soldiers and sailors for help when by April 25,1919 , the county was $\$ 150,000$ below its quota in bond sales. This led to the following front page notice in the Newton Daily News. April 25, 1919.

RESOLUTIONS passed by Patriotic Investigation Council of Jasper County. Be it resolved that we proceed at once to the investigation of reason for a number of wealthy citizens of Jasper County declining to subscribe to their share of Victory Loan and now be it resolved that we ask each and every person in Jasper County whose allotment was more than $\$ 100$ and who failed to take at least $80 \%$ of their subscription to Fourth Liberty Loan that they appear before our Organization at Court House in Newton, lowa and that no one be let off with a Subscription of less than $100 \%$ of their Fourth Liberty Loan. Signed, 30 Returned Soldiers.

The bond slackers in the county were notified by telephone by members of this Patriotic Investigation Council to appear and explain why they had failed to purchase their share of bonds. Citizens were afforded the opportunity to come before the court voluntarily, but if they did not they could be compelled to appear. In Jasper County, the court met under the direction and with the advice of the county council for defense. Meetings were held in the county courthouse.

${ }^{17}$ Wittke, p. 158. 
Eighteen citizens appeared before the court at its first meeting on April 26, 1919 and all except one purchased their share of bonds. Peter Frahm, a farmer from north of Newton, did not. His allotment was $\$ 1,350$. Evidently he bought the bonds shortly afterward as his name does not appear again. A Newton resident, W. G. Mann, told the soldiers who called and requested his presence before the court to "go to hell." Later the same day Mr. Mann felt it necessary to call the sheriff's office and demand protection. Presumably his safety and that of his family had been threatened as a result of his refusal to cooperate with the soldiers' court. ${ }^{18}$

Three days later another front page notice asked all returned servicemen to come to the courthouse for another meeting of the court where more bond slackers were to be present. Whether any alleged slackers appeared or not is unclear, but Mr. Mann ignored this meeting just as he had the first time. Since he had not chosen to appear voluntarily, guards waited for his appearance downtown the next morning and took him to the courthouse to await the arrival of members of the court. A large crowd that was pro-soldier gathered and Mann was taken out into the courthouse corridor so all could get a good look at him.

Mann maintained he could not afford any more than the $\$ 700$ worth of bonds he had purchased the day before, but a banker was located who was willing to make him a loan. Mann had to sign for additional bonds, making his investment an even $\$ 5,000$.

Mann hesitated but it was made so plain to him that it would be to his best interest in every way that he reconsidered and signed ... He had gone through one of the most grueling ordeals and cross examinations experienced by mortal man. ${ }^{19}$

The court was a very effective way of raising money: five days after its first session in Jasper County, $\$ 35,000$ was received in bond subscriptions. The Soldiers' and Sailors' Court did not meet formally again, but letters signed "By Authority of Returned Soldiers' and Sailors' Council Committee" were sent to all alleged bond slackers on May 6 saying, "We must have your subscription 
or your personal appearance before the committee." ${ }^{20}$ As a result, the Newton Daily News reported on May 29 that Jasper County had over-subscribed the Victory Loan.

Methods like those described above led to violations of the law and allowed the force of personal influence and spite to gain control over the unfortunates labeled "slackers." Such methods employed in Iowa were justified by the argument that "the American people have a power higher and greater than the Constitution or law . . . to save the Government, to save the Flag, and to save the law itself from destruction at home as well as abroad." 21

James W. Pierce, editor of the Iowa Homestead and member of the State Council for Defense, referred to the intense Liberty bond campaign period during the spring and summer of 1918 as a "reign of terror." 22

In most cases the pressure to subscribe was so heavy and the fear of the public temper, already set on a hair trigger, became so great that during the last three campaigns in Iowa virtually all that was necessary was to announce to each person the amount of his quota and he subseribed without hesitation. ${ }^{23}$

Pierce devoted a major portion of the August 22, 1918, issue of the Iowa Homestead to the pressures that citizens, especially those in rural areas, were enduring. "More harm is resulting from this assumption of authority by private individuals, without the shadow of moral or legal right, than by all the pro-German propaganda or real disloyalty in the state," wrote Pierce. "Our boasted freedom and liberty and love of fair play are being made the victims of methods no better than those of the despoilers of Belgium, from which they differ not in quality but only in degree." Several incidents of uncalled-for violence, at least in Pierce's view, unfounded accusations of disloyalty, and violations of the constitutional rights of Iowans were described in considerable detail. "Never in this commonwealth ... has lawlessness been so rampant ... [nor] the constitutional rights of citizens so outraged," he said.

These articles received front-page attention from the Des

${ }^{20}$ Ibid.

21 Proceedings of the Iowa State Bar Association, Vol. XXIV, 1918, quoted by Wittke, p. 157.

${ }^{22}$ Iowa Homestead (Des Moines, Iowa), August 22, 1918, p. 1.

${ }^{23}$ Whitney, p. 128. 
Moines Register; the State Council for Defense subsequently "fired" Pierce. Pierce maintained that the council could not fire him since he had been appointed by the governor. However, Bierce resigned from the State Council for Defense and stated that no further articles would be printed at that time. He gave as the reason for his resignation that all the furor surrounding his writings might detract from the Fourth Liberty Bond Campaign that was just getting underway.

Although none of these pressures and tactics were designed specifically to coerce the German-Americans, yet obviously they felt the weight of public opinion more than the average citizen simply because of their birth and ancestry. District chairmen in the Fourth Liberty Loan Campaign received these instructions, "Watch for disloyal remarks and report every instance since [every] derogatory rumor or report was inspired by German propaganda and that German money was paying for the starting of these rumors." ${ }^{24}$ Charges of seditious remarks, failure to buy bonds, or donate generously enough to various fund drives continued and "slacker" courts operated regardless of the question of their legality.

$$
\text { \# \# }
$$

One of the few cases emerging from this time that actually reached court was heard in June, 1918. At that time, the Reverend William Schumann of Pomeroy, Calhoun County, was convicted, in federal court, of violating the Espionage Act of June 15, 1917. The church he was serving burned under unusual circumstances in December, 1917. The government charged Schumann did ". . . willfully obstruct the recruiting and enlistment service of the United States, by delivering a sermon in a church of which he was then and there pastor." 25

Court records of the case indicate that in the sermon, Schumann said:

This war in which America is engaged is for the capitalists only and

${ }^{24}$ Des Moines Register. September 10. 1918, p. 10.

${ }^{25}$ The Federal Reporter-Cases Argued and Determined in the Circuit Courts of the United States and the Court of Appeals of the District of Columbia, September-October, 1919, Vol. 258 (St. Paul, West Publishing Co., 1919), p. 233. 
the Liberty Bond is a great humbug; by buying Liberty Bonds you buy yourself deeper into slavery; America went into this war to help England; [and] our boys should not go over and shed their blood to help England. ${ }^{26}$

Schumann's conviction was upheld by the Circuit Court of Appeals, April 28, 1919, and he served a term in the Federal Prison at Leavenworth. ${ }^{27}$

The case received much notoriety because Governor Harding tried in a telephone conversation and later in private conversation to persuade Schumann to leave Pomeroy at least until his trial. Public sentiment was so aroused the governor feared for Schumann's physical safety. Schumann could not be persuaded to leave and the local paper made reference to his trusting in the "Kaiser's God" for safety. His church, German Evangelical, was referred to as the "Kaiser's church-the Prussian Church" in the newspaper. In an attempt to explain the Reverend Schumann's character and actions the paper said:

$\ldots$ he is intensely grounded in his religious convictions, which, with his love for his mother country warps his judgment and makes him fanatical, fearing nothing because his faith that his God will protect him and that as a true disciple of his faith he must have the courage of his conviction like a Peter or a Paul. ${ }^{20}$

The minister's faith and courage, right or wrong, led to a clash and resulted in his imprisonment.

Problems with the German-Americans and others too, who questioned actions of both state and federal government continued on through the summer and fall of 1918. On the surface, it would appear that with the signing of the armistice on November 11,1918 , domestic violence would cease. This was not the case, at least not completely, for human emotion cannot be turned off so easily. At Lowden, Iowa, the pastor of the German Church was given forty-eight hours to leave town. The same crowd of victory celebrators rounded up other leading "pro-Germans," forced them to parade through town, salute the flag, and make cash con-

${ }^{20}$ The Federal Reporter, Vol. 258, p. 233. This report of what the Reverend Schumann said appears in official records of the case. The sermon actually was preached in German.

${ }^{27}$ Schumann was in prison from 1920-22. Upon his release he returned to Pomeroy and again served as pastor of the German church until 1932.

${ }^{28}$ Pomeroy Herald. May 16. 1918, p. 1. 
tributions to the Red Cross. ${ }^{29}$ On Victory Day, a Maquoketa farmer was nearly lynched for a rash remark comparing the Kaiser and a local deputy marshal. ${ }^{30}$

The Fifth Liberty Loan Campaign took place in April and May of 1919. Young men who had served in the expeditionary forces often were used by the organizers of the bond campaigns to influence bond purchases. Black Hawk County sent groups of wounded veterans to visit citizens who did not buy their quotas. In Jasper County, the county council of defense used some veterans to organize a court to investigate alleged bond slackers as described earlier. A group of soldiers from Council Bluffs received a great deal of publicity because it attempted to arrange an interview with James W. Pierce, the Iowa Homestead editor, and force him to explain his attitude as expressed in that paper.

The end of the fighting in Europe did not bring an end to the fear and distrust of the use of foreign languages. On April 10, 1919, the Thirty-eighth General Assembly enacted a law requiring that instruction in secular subjects in all schools in Iowa, public or private, had to be in the English language. Foreign languages could be taught above the eighth grade only. To further the Americanization of all Iowans, the Assembly also passed a law requiring citizenship instruction be given in the schools. ${ }^{31}$

The war had its impact on the make-up of the Iowa General Assembly, too. When the Thirty-sixth General Assembly met in 1915 , there were eight senators and twelve representatives with German names. Four representatives listed Germany as their birthplace, three were born in Norway, two in Sweden, two in England, and one in Canada with the remainder being native born. ${ }^{32}$ In 1919, when the Thirty-eighth General Assembly convened, two senators and six representatives had German names. None had been born in Germany while four members listed the British Isles as their place of birth.

${ }^{29}$ Des Moines Register, November 12, 1918, p. 10.

${ }^{30}$ Des Moines Register, November 24, 1918; Newsletter for lowa Boys in France.

${ }^{31}$ Acts and Joint Resolutions Passed at the Regular Session of the 38th General Assembly of the State of Iowa, 1919, p. 219, 535-36.

${ }^{32}$ Olficial Register, 1915-16, pp. 130-5. The matter of the German names is the author's personal judgment as there is no way to be absolutely certain in all cases. 
A new organization, the American Legion, became important in Iowa after the war. Its emphasis on Americanism and patriotism did not allow for Americans using another language. At Davenport, American Legion Post \#76 adopted a resolution condemning the use of foreign languages in churches, schools, theaters, on public conveyances and in public places. The resolution was deemed necesssary because once a month the local Lutheran Church held a German service for the benefit of older members who did not understand English. No German had been used by the church during the war. ${ }^{33}$

Although pressure to use English abated after the war it did not completely end. Americans had been encouraged during the war to view anything German with distrust and some of this feeling lingered, fading only slowly as time passed. Those German-Americans who lived through the war years would never again feel quite the same about their heritage or, perhaps, about America-for loyaity to the one required severing all ties with the other.

Governor Harding's language proclamation, combined with the anti-German feeling during World War I, caused a decline in the use of German. Although the German language was spoken more frequently in the twenties it is doubtful if it ever attained the importance it held before the war. An opportunity to appreciate and enjoy their heritage in America was denied a generation of Germans as a consequence of the pressure of the war years.

${ }^{33}$ Davenport Daily Times, November 4, 1919, in ARC. 
Copyright of Annals of Iowa is the property of State of Iowa, by \& through the State Historical Society of Iowa and its content may not be copied or emailed to multiple sites or posted to a listserv without the copyright holder's express written permission. However, users may print, download, or email articles for individual use. 